\title{
Autobiographical Memory in Depression-A Case Study
}

\author{
Katarzyna Wachowska, Kinga Bobińska, Piotr Gałecki, Monika Talarowska \\ Department of Adult Psychiatry, Medical University of Lodz, Lodz, Poland \\ Email: piotr.galecki@umed.lodz.pl
}

Received 20 January 2016; accepted 17 February 2016; published 22 February 2016

Copyright (C) 2016 by authors and Scientific Research Publishing Inc.

This work is licensed under the Creative Commons Attribution International License (CC BY). http://creativecommons.org/licenses/by/4.0/

(c) (i) Open Access

\begin{abstract}
Introduction: Autobiographic memory allows shaping self identity over the time. Its main function is storing of information about oneself, which allows consolidating one's own identity and provides the sense of stability. Its disfunction might be organic or functional in origin and may often be a manifestation of a serious disease. Aim: The purpose of the study was to compare cognitive functioning in the scope of autobiographical memory between a female patient with diagnosed dissociative amnesia and five female patients with diagnosed recurrent depressive disorders. Method: The following tools were used in the study: episodic memory test and MMPI-2 questionnaire (Gough Dissimulation Index). Results: The general results achieved by patient diagnosed with dissociative amnesia in the individual tasks used to examine autobiographical memory are comparable with the results achieved by the patients with diagnosed depression. However, the results suggest the presence of qualitative differences related to the type of remembered information and location of the events on the life line.
\end{abstract}

\section{Keywords}

Depression, Autobiographic Memory, Dissociative Amnesia

\section{Introduction}

Autobiographical memory is a specific type of memory where a material regarding a given person's individual life history is stored (Maruszewski, 2005). Thanks to autobiographical memory, a person is able to determine their own identity over the course of time as well as to shape their personality (Reinhold \& Markowitsch, 2009). Conway (2001) indicates that the main function of autobiographical memory is storing of information about oneself, which allows consolidating one's own identity and provides the sense of stability and continuation (Conway, 2001). Maruszewski (2005) claims that this memory should be referred to as declarative memory re- 
garding the past (Maruszewski, 2005).

A repository of autobiographical memory contains information of both the semantic and episodic nature. The information is encoded in the form of narratives, i.e. a series of events, and as information concerning facts (name, surname, dates). The repository also contains interpretations and abstract data. What distinguishes autobiographical memory from other memory types is the high emotional charge of the material stored in it (Maruszewski, 2005). According to researchers, the data contained in autobiographical memory are characterised by a sequential order, understood by a given person, and by accurate determination of time (Maruszewski, 2004).

Autobiographical memory disorders are a serious symptom. Most generally, we may claim that the causes of such disorders may be:

- Organic (e.g. condition after traumas of the central nervous system, dementia processes, neurodegenerative diseases),

- Or functional (e.g. dissociative disorders, affective diseases, stress-related disorders).

Dissociation is referred to as a disorder of mental functions, which may occur in different forms: amnesia, depersonalisation, dissociation, identity disorders (Sar, 2014). Dissociative disorders are linked with a response to stress (Reinhold \& Markowitsch, 2009), (Sar, 2014). They can be either acute or chronic (Sar, 2014). Dissociative amnesia is a mental disorder characterised by amnesia of events from the past (retrograde amnesia) and a defective sense of the affected person's identity. Memory disorders are usually associated with a traumatic event (Rabe-Jabłońska, 2015). Learning new information is intact (recent memory, ability of learning new information) (Rabe-Jabłońska, 2015). The area covered by amnesia is diverse: complete amnesia of the past or amnesia regarding only selected periods from one's own life (Reinhold \& Markowitsch, 2009).

Different authors describe cases of disorders in the cognitive functioning of patients with diagnosed depressive disorders, both during the first episode of the disease as well as in case of recurrent disorders. They mainly affect memory, attention and executive functions (Mueller-Pfeiffer, Rufibach, Perron, Wyss, Kuenzler, Prezewowsky, Pitman, \& Rufer, 2012), (Talarowska, Zajączkowska, \& Gałecki, 2015). With reference to memory, this mainly affects short-term and episodic memory (Talarowska, 2009).

\section{Purpose}

The purpose of the study was to compare cognitive functioning in the scope of autobiographical memory between a female patient with diagnosed dissociative amnesia and female patients with diagnosed recurrent depressive disorders.

\section{Material}

Seven female patients, hospitalised at the Clinic of Adult Psychiatry of the Medical University of Lodz, were qualified for the study:

Patient A.A., aged 29, hospitalised psychiatrically for the first time, treated on an outpatient basis for several months due to diagnosed depressive disorders. Ten years earlier the patient was involved in an accident, as a result of which she suffered from head injuries. According to the patient, she had problems recollecting events from her own life after the accident, and the difficulties are still present. The patient informed that her parents had to tell her specific details about her childhood. Besides the disorders in the scope of autobiographical memory functioning, the patient mentioned that directly after the accident she had also suffered from: deteriorated concentration, reduced ability of learning, cognitive fatigability. At the beginning of this year, the patient started to complain about dysphoria, discouragement, loss of motivation and sleeping disorders. Table 1 presents details of the patients qualified for the study.

The study design was given a positive opinion by the Bioethics Commission at the Medical University of Lodz, and each person examined provided written and informed consent for the participation in the study.

\section{Method}

The following tools were used in the study: episodic memory test and MMPI-2 questionnaire.

The episodic memory test was developed on the basis of existing literature, questionnaires used in the examination of autobiographical memory and the researchers' own concepts. The test was composed of three parts: the first two were developed by the authors of the study, while the third part was based on the existing questionnaires used to evaluate autobiographical memory. 
Table 1. Details of the patients qualified for the study.

\begin{tabular}{|c|c|c|c|c|c|c|}
\hline Patient & Age & Education & $\begin{array}{l}\text { Duration of psychiat- } \\
\text { ric treatment in years }\end{array}$ & Diagnosis & Hospitalisation & Psychiatric treatment \\
\hline A.A. & 29 & Higher & 0 & $\begin{array}{l}\text { Mixed dissociative } \\
\text { disorders }\end{array}$ & First & $\begin{array}{l}\text { Treated on an outpatient } \\
\text { basis for several months } \\
\text { after diagnosis of } \\
\text { depressive disorders }\end{array}$ \\
\hline B.B. & 32 & Secondary & 10 & $\begin{array}{l}\text { Recurrent depressive } \\
\text { disorders }\end{array}$ & Successive & $\begin{array}{l}\text { Treated for } 10 \text { years } \\
\text { due to recurrent } \\
\text { depressive disorders }\end{array}$ \\
\hline C.C. & 24 & Secondary & 3 & $\begin{array}{l}\text { Recurrent depressive } \\
\text { disorders }\end{array}$ & Successive & $\begin{array}{l}\text { Treated for } 3 \text { years } \\
\text { due to recurrent } \\
\text { depressive disorders }\end{array}$ \\
\hline D.D. & 39 & Basic & 0 & $\begin{array}{l}\text { Recurrent depressive } \\
\text { disorders }\end{array}$ & First & $\begin{array}{c}\text { Not treated } \\
\text { psychiatrically before }\end{array}$ \\
\hline E.E. & 23 & Secondary & 3 & $\begin{array}{l}\text { Recurrent depressive } \\
\text { disorders }\end{array}$ & Successive & $\begin{array}{l}\text { Treated for } 3 \text { years } \\
\text { due to recurrent } \\
\text { depressive disorders }\end{array}$ \\
\hline F.F. & 25 & Higher & 0 & $\begin{array}{l}\text { Recurrent depressive } \\
\text { disorders }\end{array}$ & First & $\begin{array}{l}\text { Not treated } \\
\text { psychiatrically before }\end{array}$ \\
\hline G.G. & 41 & Secondary & 6 & $\begin{array}{l}\text { Recurrent depressive } \\
\text { disorders }\end{array}$ & First & $\begin{array}{c}\text { Treated psychiatrically for } \\
6 \text { years due to recurrent } \\
\text { depressive disorders }\end{array}$ \\
\hline
\end{tabular}

Task 1 involved putting in a table dates of personal events which took place during the examined person's lifetime and social life events.

Task 2 was the so-called "life line" where the examined individuals were asked to provide a short description with dates of events from their own life.

Task 3 was a set of questions in the form of a structured interview (Maruszewski, 2005), which included different aspects and periods of the given person's life (names, surnames, birthdays, circumstances of acquiring skills, data concerning education, recollections of toys, etc.).

The MMPI-2 test was developed by Starke R. Hathaway and J. Charnley McKinley, who wanted to work out a tool that enabled an objective evaluation of the psychotherapy effects and changes in the psychological functioning of an individual. Besides content-related scales, it also included control scales which allowed evaluating the examined person's attitude towards the study. It is best if the person cooperates and is serious, as well as reads carefully each question and provides answers based on his or her own reflections. Various factors, however, may result in an opposite approach. Besides the results obtained in the control scales, their mutual configuration must also be taken into account (Kucharski \& Gomuła, 1998), (Płużek, 1969). Among the many parameters evaluated using the MMPI-2 test, the Gough Dissimulation Index was applied in this study in order to determine the patients' attitude to the situation connected with the examination. The Index is calculated based on raw score in two control scales: $\mathrm{F}$ and $\mathrm{K}$, based on the following formula: $\mathrm{F}-\mathrm{K}$. The result provides information about the examined person's attitude towards the examination —if the value exceeds +9 the person's attitude is considered malingering and a value lower than -11 suggests a tendency to dissimulation (Płużek, 1969).

\section{Results}

Table 2 presents the results achieved by the patients.

The general results achieved by patient A.A. in the individual tasks used to examine autobiographical memory are comparable with the results achieved by the patients with diagnosed depression.

A detailed analysis enables to observe that in Task 1 patient A.A. mentioned the most recollections regarding the events both from her personal life and from social life among all the individuals examined in the study (task 
Table 2. The results achieved by the patients qualified for the study.

\begin{tabular}{|c|c|c|c|c|c|c|}
\hline & MMPI-2 & & Task 1 & & Task 2 & Task 3 \\
\hline Patient & $\begin{array}{c}\text { Gough } \\
\text { Dissimulation } \\
\text { Index (F-K) }\end{array}$ & $\begin{array}{l}\text { Column 1: } \\
\text { events from } \\
\text { personal life }\end{array}$ & $\begin{array}{l}\text { Column 2: } \\
\text { events from } \\
\text { social life }\end{array}$ & $\begin{array}{l}\text { Number of } \\
\text { associated } \\
\text { dates }\end{array}$ & $\begin{array}{l}\text { Ratio of the number } \\
\text { of recollections per year of life } \\
\text { (rounded to two decimal places) }\end{array}$ & $\begin{array}{l}\text { Structured } \\
\text { interview-total } \\
\text { number of points } \\
\text { (max }=33 \text { points) }\end{array}$ \\
\hline A.A. & -5 & 12 & 10 & 3 & 0.38 & 24 \\
\hline B.B. & 16 & 10 & 1 & 0 & 0.44 & 25 \\
\hline C.C. & 8 & 10 & 4 & 4 & 0.75 & 33 \\
\hline D.D. & 12 & 0 & 8 & 0 & 0.72 & 33 \\
\hline E.E. & 12 & 2 & 2 & 2 & 0.09 & 22 \\
\hline F.F. & 7 & 8 & 0 & 0 & 0.52 & 20 \\
\hline G.G. & -7 & 0 & 0 & 0 & 0.39 & 17 \\
\hline
\end{tabular}

1, column 1 and 2). Attention needs to be paid to a particularly large number of events from social life (10) as compared to other study participants. The majority of the remaining patients provided a lot fewer events from social life (from 0 to 4 ), except for patient D.D. (8 events from social life). It needs to be underlined that all of the events from social life mentioned by A.A. had taken place before the date of the accident and some of them had occurred even before the birth of the patient. Only three patients, i.e. A.A., C.C. and E.E., were able to combine events from both social life and their personal life in one date. A.A. indicated 3 dates in this way, C.C.-4, and E.E.-2.

During Task 2 (life line) the patient mentioned few recollections (11), seven of which had taken place before the accident, one recollection was connected with the accident, and only two referred to the period after the accident. The remaining patients provided a diversified number of recollections-from 2 (E.E.) to 28 (D.D.). Considering the patients' age, the highest ratio of the number of recollections per year of life was achieved by patient C.C. (0.75), while the lowest by E.E. (0.09). In qualitative terms, the majority of the patients described events evenly distributed in time, with average intervals between recollections from 2.1 to 3.6 years. Patient E.E. was an exception, who provided only two events, both from her childhood, with an interval of 8 years. The last event described on the life line was at a distance from 0 (C.C., F.F.) to 5 (G.G.) years from the yearly date of the examination, except for patient E.E. (15 years).

In Task 3 (structured interview) the patient provided a lot of information of a semantic character: names, surnames, names of places, information about family members (birthdays, number of siblings), details concerning education; however, with reference to the questions regarding recollections of a narrative character (toys or acquiring skills) the patient either said she "didn't remember" or she had received specific information from other family members. Patients B.B. and E.E. achieved a similar number of points ( 25 and 22, respectively). As compared to patient A.A. they did not know answers to some of the questions regarding semantic data concerning family members, while both of them provided precise information about their first toy. Both A. A. as well as B.B. and E.E. found it difficult to recall the circumstances of acquiring the ability to ride a bicycle. F.F. and G.G. had smaller number of points (20 and 17, respectively). In comparison to patient A.A., they provided less information of a semantic character regarding family members; they also found it difficult to recall the circumstances of acquiring certain skills (G.G.). Meanwhile, both of them provided a lot of information about their first toy. Patients C.C. and D.D. answered all the questions and received the maximum number of points.

\section{Conclusion and Discussion}

When analysing the detailed responses of patient A.A. in individual parts of the test and by comparing them with the responses of the patients treated due to recurrent depressive disorders, it is possible to observe qualitative differences, mainly referring to:

- A large number of events from social life as compared to the remaining patients.

- Difficulties in presenting recollections of a narrative character. 
- Ease in recalling information of a semantic character.

- Irregular distribution of recollections on the life line, with the dominance of events preceding the accident.

It is appropriate to state that the large amount of information concerning social life (including before the patient's birth) described by patient A.A. may be directly associated with her education. They are examples of semantic knowledge (e.g. date of world war end), which are not A.A.'s recollections. What is interesting is that the patient did not describe events of a social character dated after the accident in which she was involved. Moreover, attention needs to be paid to the irregular distribution of events on the life line; the patient described more of them in the period before the accident, i.e. in the period of declared retrograde amnesia. During one of the tasks, the patient emphasised that she had acquired certain information from her relatives.

The relative ease of recollecting information of a semantic character (surnames, dates, places) may be associated with the necessity of repeating such information (e.g. in documents, application forms, etc.) and the patient could also use the help of her relatives in this aspect. This is also how Tulving (2002) explains the case of patient K.C., whose amnesia is however associated with a brain injury and has both a retrograde and consequent character (Tulving, 2002).

Dissociative memory disorders may resemble disorders which are a manifestation of brain damage, i.e. have an organic origin (Arzy, Collette, Wissmeyer, Lazeyras, Kaplan, \& Blanke, 2011). Hart indicates that confirming the psychogenic aetiology of memory disorders does not exclude coexisting organic factors, which may shape the picture of the disorder in a given patient (Hart \& Nijenhuis, 2001). However, there are several characteristic features which indicate the dissociative (psychogenic) basis of the observed ailments. The fundamental one is the loss of sense of own identity, which may be linked with the changes in behaviour and personality (Reinhold \& Markowitsch, 2009), (Arzy, Collette, Wissmeyer, Lazeyras, Kaplan, \& Blanke, 2011), (Talarowska, Zajączkowska, Wachowska, \& Gałecki, 2013). Observed amnesia is selective (although there are cases of generalised amnesia (Hart \& Nijenhuis, 2001), its symptoms become aggravated with time, and patients have an ability to acquire new information. The information concerning the patient's identity and skills is maintained, e.g. associated with a given profession. The disorder often affects young people and is accompanied by dysphoria, although patients have ambivalent feelings towards amnesia (Reinhold, \& Markowitsch, 2009), (Talarowska, Zajączkowska, Wachowska, \& Gałecki, 2013). The phenomenon of "leaking” of certain information may take place; cases of sudden memory recovery are also described (Hart \& Nijenhuis, 2001). The occurrence of dissociative amnesia may be linked with experiences of violence or trauma during childhood (Arzy, Collette, Wissmeyer, Lazeyras, Kaplan, \& Blanke, 2011), (Hart \& Nijenhuis, 2001), (Mueller-Pfeiffer, Rufibach, Perron, Wyss, Kuenzler, Prezewowsky, Pitman, \& Rufer, 2012), and may have its onset after a mild head injury connected with preceding stress (Reinhold \& Markowitsch, 2009).

\section{Source of support}

This study was supported with funding from the Medical University of Lodz grant No. 502-03/5-062-02/502-54085.

\section{References}

Arzy, S., Collette, S., Wissmeyer, M., Lazeyras, F., Kaplan, P. W., \& Blanke, O. (2011). Psychogenic Amnesia and Self-Identity: A Multimodal Functional Investigation. European Journal of Neurology, 18, 1422-1425.

Conway, M. A. (2001). Sensory-Perceptual Episodic Memory and Its Context: Autobiographical Memory. Philosophical Transactions: Biological Sciences, 356, 1375-1384. http://dx.doi.org/10.1098/rstb.2001.0940

Hart, O., \& Nijenhuis, E. (2001). Generalized Dissociative Amnesia: Episodic, Semantic and Procedural Memories Lost and Found. Australian and New Zealand Journal of Psychiatry, 35, 589-600. http://dx.doi.org/10.1080/0004867010060506

Kucharski, T., \& Gomuła, J. (1998). Wprowadzenie do kwestionariusza MMPI-2 Toruń: Pracownia Psychologii Klinicznej i Rozwoju Osobowości.

Maruszewski, T. (2004). Pamięć autobiograficzna jako podstawa tworzenia doświadczenia indywidualnego w: Strelau J. (ed.) Psychologia T2 GWP Gdańsk.

Maruszewski, T. (2005). Pamięć autobiograficzna. Gdańsk: GWP.

Mueller-Pfeiffer, C., Rufibach, K., Perron, N., Wyss, D., Kuenzler, C., Prezewowsky, C., Pitman, R. K., \& Rufer, M. (2012). Global Functioning and Disability in Dissociative Disorders. Psychiatry Research, 200, 475-481. http://dx.doi.org/10.1016/j.psychres.2012.04.028 
Płużek, Z. (1969). Wartość diagnostyczna testu WISKAD-MMPI w zakresie nozologii psychiatrycznej. Roczniki filozoficzne, 17, 125-143.

Rabe-Jabłońska, J. (2015). Zaburzenia Nerwicowe in: Jarema M. Rabe-Jabłońska J. Psychiatria. Podręcznik dla studentów medycyny PZWL Warszawa.

Reinhold, N., \& Markowitsch, H. J. (2009). Retrograde Episodic Memory and Emotion: A Perspective from Patients with Dissociative Amnesia. Neuropsychologia, 47, 2197-2206. http://dx.doi.org/10.1016/j.neuropsychologia.2009.01.037

Sar, V. (2014). The Many Faces of Dissociation: Opportunities for Innovative Research in Psychiatry. Clinical Psychopharmacology and Neuroscience, 12, 171-179. http://dx.doi.org/10.9758/cpn.2014.12.3.171

Talarowska, M. (2009). Funkcje poznawcze w depresji. Psychiatria Polska, XLIII, 31-40.

Talarowska, M., Zajączkowska, \& Gałecki, P. (2015). Cognitive Functions in First-Episode Depression and Recurrent Depressive Disorder. Psychiatria Danubina, 27, 38-43.

Talarowska, M., Zajączkowska, M., Wachowska, K., \& Gałecki, P. (2013). Autobiographical Memory Disturbance or Psychogenic Amnesia? A Case Report 2013. Basic and Clinical Psychiatry, 1, 1-6.

Tulving, E. (2002). Episodic Memory: From Mind to Brain. Annual Review of Psychology, 53, 1-25.

http://dx.doi.org/10.1146/annurev.psych.53.100901.135114

\section{Submit or recommend next manuscript to SCIRP and we will provide best service for you:}

Accepting pre-submission inquiries through Email, Facebook, Linkedin, Twitter, etc A wide selection of journals (inclusive of 9 subjects, more than 200 journals)

Providing a 24-hour high-quality service

User-friendly online submission system

Fair and swift peer-review system

Efficient typesetting and proofreading procedure

Display of the result of downloads and visits, as well as the number of cited articles

Maximum dissemination of your research work

Submit your manuscript at: http://papersubmission.scirp.org/ 